\title{
Tufting enteropathy with EpCAM mutation: case report
}

\section{Enteropatia com formação de tufos epiteliais e mutação do gene EDCAM: relato de caso}

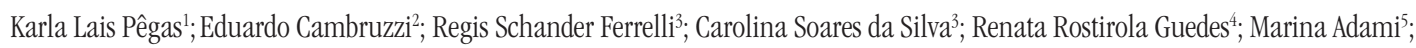
Eduardo Montagner Dias ${ }^{3}$; Melina Utz Melere ${ }^{3}$; Marilia Rosso Ceza ${ }^{3}$; Cintia Steinhaus ${ }^{3}$; Matias Epifanio ${ }^{6}$; Julie Salomon7 Cristina Targa Ferreira $^{8}$

\begin{abstract}
Tufting enteropathy (TE), also known as intestinal epithelial dysplasia (IED), is a rare congenital enteropathy related to an earlyonset of severe intractable diarrhea due to specific abnormalities of the intestinal epithelium and mutations of the EpCAM gene. TE is characterized by clinical and histological heterogeneity, such as with low or without mononuclear cell infiltration of the lamina propria, and abnormalities of basement membrane. TE can be associated with malformations, other epithelial diseases, or to abnormal enterocytes development and/or differentiation. The authors report a case of a Brazilian child with TE associated with c.556-14A $>\mathrm{G}$ mutation in the EpCAM gene (NM_002354.2).
\end{abstract}

Key words: tufting enteropathy; intractable diarrhea; intestinal mucosa; epithelial cell adhesion molecule; EpCAM gene.

\section{INTRODUCTION}

Tufting enteropathy (TE), also known as intestinal epithelial dysplasia (IED), is a rare disorder that causes chronic watery diarrhea, and is characterized by the presence of focal epithelial "tufts" composed of clusters of closely packed enterocytes with round, teardrop-shaped projections in the apical cytoplasm. TE is present in the first few months of life, and most patients require total parenteral nutrition to acquire adequate caloric and fluid intake for normal growth and development ${ }^{(3,5,6,8)}$.

TE was first described in 1994, and its prevalence can be estimated at around 1/50.000-100.000 live births in Western Europe. Mutations in the epithelial cell adhesion molecule (EpCAM) gene have been associated with TE. EpCAM acts as a typical cell-cell adhesion molecule, once it is connected to the actin cytoskeleton, and mediates homotypic interactions between intraepithelial lymphocytes and intestinal epithelial cells, during the origination of the innate immune system $^{(6,8,11,13,21)}$. The authors describe the first case documented in Brazil of TE due to c.556-14A>G mutation in the EpCAM gene (NM_002354.2). The authors also discuss the molecular aspects, morphologic findings, and clinical evaluation of this uncommon disease.

\section{Case report}

A female infant was attended in pediatric services due to soften stools, delayed growth, and failure to gain weight. The diarrhea was not severe and was not treated as intractable diarrhea. Cow's milk

First submission on 22/12/13; last submission on 09/03/14; accepted for publication on 10/03/14; published on 20/06/14

1. MSc in Pathology at Universidade Federal de Ciências da Saúde de Porto Alegre (UFCSPA); pathologist at Santa Casa de Porto Alegre (ISCMPA).

2. Postdoctoral student in Cardiovascular Pathology, Instituto de Cardiologia at Fundação Universitária de Cardiologia (IC-FUC); pathologist; pathology professor at Universidade Federal do Rio Grande do Sul (UFRGS), and Universidade Luterana do Brasil (ULBRA).

3. Pediatric Gastroenterologist at Santa Casa de Porto Alegre.

4. Masters student in Gastroenterology at UFRGS; pediatric gastroenterologist at Santa Casa de Porto Alegre.

5. Pediatric gastroenterologist at Santa Casa de Porto Alegre and Hospital de Clínicas de Porto Alegre (HCPA)

6. MD in Pediatrics and Child Health at Pontifícia Universidade Católica do Rio Grande do Sul; pediatric gastroenterologist at Santa Casa de Porto Alegre.

7. Pediatric Gastroenterologist and Hepatologist at Necker Enfants-Malades Hospital, Paris, France.

8. MD in Gastroenterology at UFRGS; pediatric gastroenterology; professor at UFCSPA; chief of pediatric gastroenterology and hepatology Department at Hospital da Criança Santo Antônio. 
protein allergy was initially suspected as the first clinical diagnostic hypothesis in other services. The patient was submitted to upper digestive endoscopy and colonoscopy because several diet regimens have been failed. The histopathology was considered normal at first. When she was 14 months old she attended our hospital and was hospitalized to investigate a severe failure to thrive. During this hospitalization, the patient received exclusively amino acid based formula diet $(180 \mathrm{kcal} / \mathrm{kg} /$ day $)$, using a nasogastric tube, without significant weight gain. Intestinal biopsies (Figure) were reviewed and revealed rare and small epithelial closely packed enterocytes clusters, with round, teardrop-shaped projections in the apical cytoplasm, associated with focal abnormal regeneration with crypts branching. These abnormalities were more common in the terminal ileum and right colon, but not in the duodenum. The number of intraepithelial lymphocytes was normal. Samples of deoxyribonucleic acid (DNA) and mucosal biopsies were sent to pathology laboratory at Necker Enfants-Malades Hospital, Paris, France, for genetic analysis. Sequencing analysis of EpCAM gene using PCR technique revealed a homozygous state for the mutation in the EpCAM gene (NM_002354.2) in intron 5'. Patient's parents were heterozygous for the EpCAM gene. The mutation was identified by sequencing the intron with replacement of 14 bases upstream of the exon 6 (c.556-14A $>\mathrm{G})$. The diagnosis of intestinal dysplasia was then established. Currently, the patient is 21 months of life, she shows body mass index z score (0.9), and height 32.5\% percentiles. She is receiving parenteral nutrition (12 hours at home) associated with hypoallergenic diet. Clinical episodes of diarrhea are unusual at this moment.

\section{DISCUSSION}

TE is a rare congenital abnormality of intestinal mucosa development leading to severe malabsorption and significant morbidity and mortality. TE is also characterized by clinical and histological heterogeneity, and possible association with other epithelial diseases or malformations, such as choanal atresia, dysmorphic face, esophageal atresia, imperforate anus, and skeletal dysplasia. In general, children with TE develop watery diarrhea in the first few days after birth. Stool volume may be as high as $100-200 \mathrm{ml} / \mathrm{kg}$ of body weight per day, with electrolyte levels similar to those of small intestinal fluid. The growth is impaired, and the disease affects most commonly patients with closer degree of consanguinity. Our patient presented atypical clinical features with minimal diarrhea episodes but severe malnutrition. In contrast to previous reports in the literature, this case showed an uncommon late-onset of clinical symptoms $^{(2,4,5,6,9,12,14,16)}$.
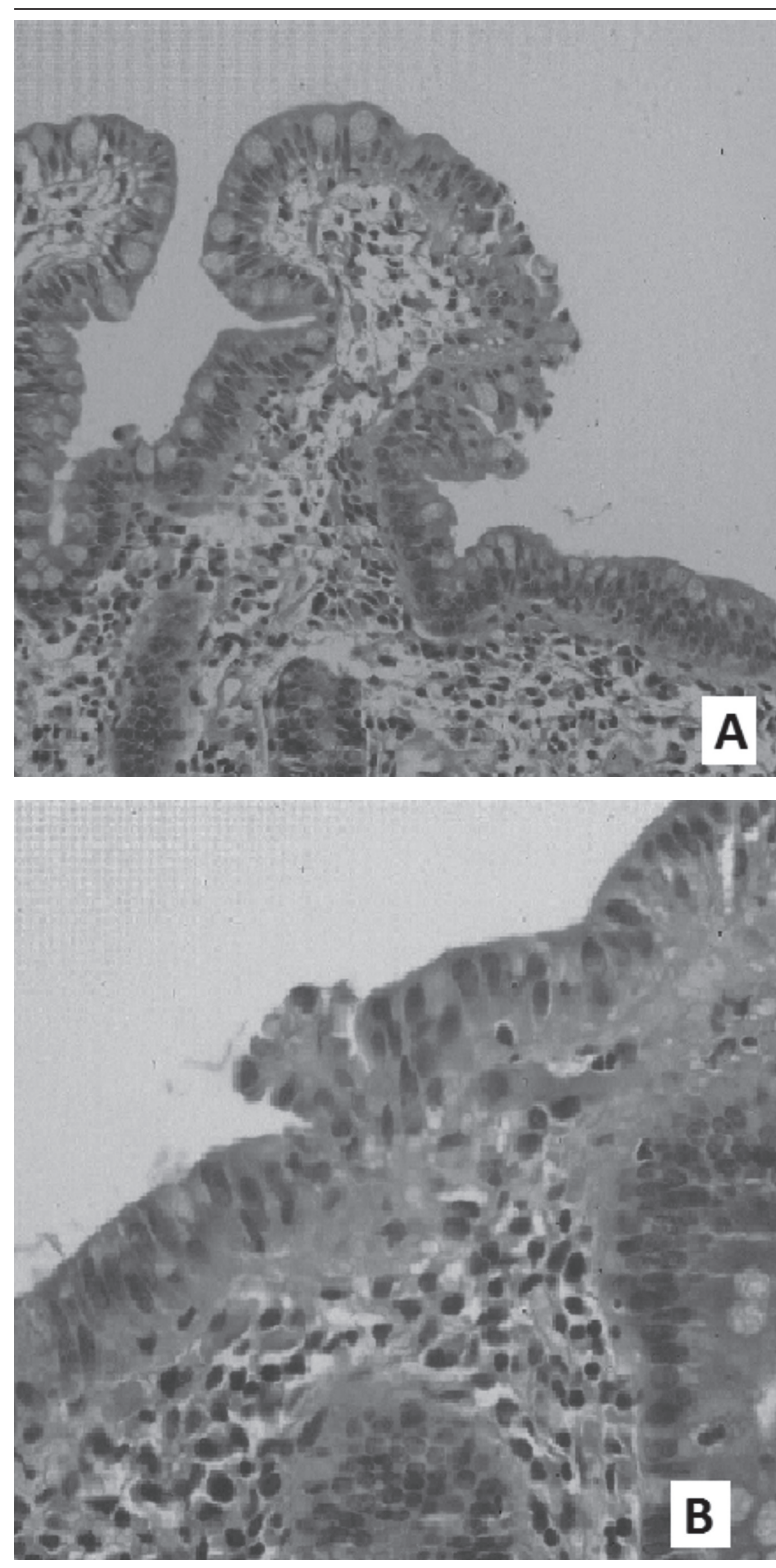

FIGURE - Tufting enteropathy

A) disorganization of surface enterocytes with focal resembling tufts in small bowel biopsy, HE, 100×; B) epithelial tufts in large bowel biopsy, HE, 100×. HE: hematoxylin-eosin stain.

The microscopic examination revealed the presence of focal crowding, resembling "tufts", composed of closely packed enterocytes clusters with round, teardrop-shaped projections in the apical cytoplasm, which is the hallmark of the disease. These tufts are predominantly identified on the mucosa of the small intestine. Other histological abnormalities include partial or total villous atrophy, basement membrane abnormalities, Paneth cell hyperplasia, and dilation and/or abnormal regeneration with branching crypts. There is no increase in 
inflammatory cells within the lamina propria. Intraepithelial lymphocytes are normal in number ${ }^{(1,5-7,10,11,13,17,20)}$. In contrast with the literature, in our report, the epithelial tufts were found in the terminal ileum and right colon instead of the duodenal mucosa, although we observed partial villous atrophy in duodenum biopsy. Abnormal deposition of laminin and heparan sulfate proteoglycans in the basement membrane, increased expression of desmogleins, a protein of cadherin family which is related to the desmosomes formation, have been described in some cases of TE. Basement membrane molecules may be related to the development and maintenance of the intestinal epithelium, which involves proliferation and differentiation of stem cells at the crypts bottom and maturation of these new cells. An abnormal distribution of $\alpha_{2} \beta_{2}$ integrin and the increase in number and length of the desmosomes between enterocytes have been associated with patients who developed TE, which can suggest that abnormalities in cell-cell adhesion is an important step in the pathogenesis of this disease $e^{(1,5-7,10,11,13,17,20)}$.

Mutations in the EpCAM gene have been associated with TE. EpCAM is encoded by the GA-733-2 gene located on chromosome 4. EpCAM was first found to play a role in homotypic cell-cell adhesion in epithelium, since it is connected to the actin cytoskeleton. EpCAM is directly associated with claudin-7, a tight junction protein, and is colocalized with E-cadherin in sites of cellcell junctions. EpCAM is able to recruit intracellular $\alpha$-actin to the sites of homotypic contacts, and the mutations in this gene can disrupt the association with $\alpha$-actin, claudin-7, or E-cadherin, which determine loss of mucosal integrity, and formation of the typical tufts observed in TE. Tufts correspond to nonapoptotic epithelial cells at the villous tips that are no longer in contact with the basement membrane. Actually, eight distinct EpCAM mutations have been identified, resulting in a single amino acid exchange, premature truncation or partial deletion of the EpCAM protein, which inhibit the formation of homotypic cell adhesion. EpCAM can mediate too homotypic interactions between intraepithelial lymphocytes and intestinal epithelial cells during the origination of the innate immune system. EpCAM (also known as EGP40, GA733-2, ESA, KSA, Trop-1, CD326, and 17-1A antigen) is expressed on the basolateral cell surface in most human simple epithelia, in special in the small bowel and colon. Normal squamous stratified epithelia are negative for EpCAM. The level of EpCAM expression correlates with the proliferative activity of intestinal cells, and inversely correlates with their differentiation. It is frequently upregulated in colon carcinomas $(7,8,9,11,13,15,17,20)$. Schnell et al. described that all mutations related to TE were homozygous or compound heterozygous, which is consistent with autosomal recessive inheritance. In this report, $\mathrm{C} 66 \mathrm{Y}$ corresponded only to the heterozygous mutation ${ }^{(18)}$. Ko et al. described two compound heterozygous mutations in siblings affected by TE: a donor splice site mutation in intron $5(\mathrm{c} .491+1 \mathrm{G}>\mathrm{A})$, and a novel nonsense mutation in exon 3 (c.316A $>$ T, Lys106X) ${ }^{(9)}$.

TE should be suspected in neonates presenting early-onset of an intractable diarrhea, without clinical evidences of infectious or inflammatory process associated. The differential diagnosis of TE includes repeated episodes of severe diarrhea related to defect in ions transport. Microvillous inclusion disease is a severe enteropathy due to defective formation. It is associated with watery diarrhea, and often presents on the first day of life. The underlying defect is thought to be a genetic alteration that leads to abnormal transport of membrane proteins to the apical surface of the epithelial cells. Small intestine biopsies demonstrate the presence of villous atrophy, with little or no associated crypt hyperplasia. The epithelium lining the villus appears disorganized, with piled up cells with vacuolated apical cytoplasm in rare and small focus. Microvillous inclusions in surface epithelial cells can be observed at transmission electron microscopy, and are most commonly found in the apical cytoplasm. The inclusions are lined by a complete brush border that includes the microvillous membrane, microfilaments, the terminal web, and a surface filamentous coat ${ }^{(5,6,16,19)}$.

The outcome of the disease varied considerably when analyzed the different clinical reports described in the international literature, and a few longitudinal studies are available on patients with TE. Most patients have been treated with long-term nutrition in order to remain adequately nourished for normal growth and development. TE can cause intestinal failure, that is clearly irreversible in most patients, and liver disease, including cirrhosis, may be developed due underlying digestive disease and an unadapted parenteral

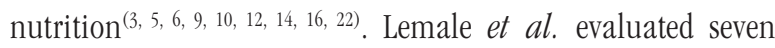
children with TE during a mean time of 6.5 years, all from consanguineous parents. In this report, 3 children were permanently weaned off parenteral nutrition, and developed normal growth without nutritional assistance. Initial biopsies of these children revealed severe diffuse histological lesions. During weaning off parenteral nutrition, 2 of these 3 patients had persistent, mild histological lesions ${ }^{(10)}$. Different EpCAM mutations seem to be associated with different outcomes in TE. Thus, the heterogeneity of the clinical manifestations and histological findings could correspond to different cellular and genetic mechanisms. Intestinal transplantation can be a feasible treatment for intestinal failure ${ }^{(1,5,6,8-10,12-14,22)}$. 


\section{RESUMO}

Enteropatia com formação de tufos epiteliais (ETE), também conhecida como displasia epitelial intestinal (DEI), é uma rara enteropatia congênita relacionada com um início precoce de diarreia intratável grave devido a anormalidades específicas do epitélio intestinal e mutações do gene EDCAM. ETE caracteriza-se por uma beterogeneidade clínica e histológica, como ausência ou leve infiltrado de células mononucleares na lâmina própria e anormalidades de membrana basal. Pode ser associada a malformações, outras doenças epiteliais ou anormalidades no desenvolvimento/na diferenciação dos enterócitos. Os autores relatam um caso de ETE, em uma criança brasileira, associada à mutação c.556-14A> g do gene EPCAM (NM_002354.2).

Unitermos: enteropatia com tufos epiteliais; diarreia intratável; mucosa intestinal; molécula de adesão das células epiteliais; gene EPCAM.

\section{REFERENCES}

1. AL-MAYOUF, S. M. et al. Tufting enteropathy and chronic arthritis: a newly recognized association with a novel EpCAM gene mutation. J Pediatr Gastroenterol Nutr, v. 49, n. 5, p. 642-4, 2009.

2. BIRD, L. M. et al. A new syndrome of tufting enteropathy and choanal atresia, with ophtalmologic, hematologic and hair abnormalities. Clin Dysmorphol, v. 16, n. 4, p. 211-21, 2007.

3. CAMERON, D. J.; BARNES, G. L. Successful pregnancy outcome in tufting enteropathy. J Pediatr Gastroenterol Nutr, v. 36, p. 158, 2003.

4. EL-MATARY, W. et al. Tufting enteropathy and skeletal dysplasia: is there a link? Eur J Pediatr, v. 166, n. 3, p. 265-8, 2007.

5. GAMBARARA, M. et al. Intractable diarrhea of infancy with congenital intestinal mucosa abnormalities: outcome of four cases. Transplant Proc, v. 35, n. 8, p. 3052-3, 2003.

6. GOULET, 0. et al. Intractable diarrhea of infancy with epithelial and basement membrane abnormalities. J Pediatr, v. 127, p. 212-9, 1995.

7. GUERRA, E. et al. MTrop1/EpCAM knockout mice evelop congenital tufting enteropathy through dysregulation of intestinal E-cadherin/ B-catenin. PLoS One, v. 7, n. 11, p. E49302, 2012.

8. KELLERMAYER, R. Congenital tufting enteropathy in the era of molecular genetics.J Pediatr Gastroenterol Nutr, v. 53, n. 3, p. 355, 2011.

9. KO, J. S. et al. Tufting enteropathy with EPCAM mutations in two siblings. Gut Liver, v. 4, n. 3, p. 407-10, 2010.

10. LEMALE, J. et al. Intractable diarrhea with tufting enteropathy: a favorable outcome is possible. J Pediatr Gastroenterol Nutr, v. 52, n. 6 , p. 734-9, 2011.

11. LITVINOV, S. V. et al. Ep-CAM: a human epithelial antigen is a homophilic cell-cell adhesion molecule.JCB, v. 125, n. 2, p. 437-46, 1994.

12. PARAMESH et al. Isolated small bowel transplantation for tufting enteropathy.J Pediatr Gastroenterol Nutr, v. 36, n. 1, p. 138-40, 2003.
13. PATEY, N. et al. Distribution of cell adhesion molecules in infants with intestinal epithelial dysplasia (tufting enteropathy). Gastroenterol, v. 113, n. 3, p. 833-43, 1997.

14. REIFEN, R. M. et al. Tufting enteropathy: a newly recognized clinicopathological entity associated with refractory diarrhea in infants. J Pediatr Gastroenterol Nutr, v. 18, p. 379-85, 1994.

15. SALOMON, J. et al. A founder effect at the EPCAM locus in congenital tufting enteropathy in the Arabic Gulf. Eur J Med Genet, v. 54, n. 3 , p. 319-22, 2011.

16. SCHERMAN, P. M.; MITCHELL, D. J.; CUTZ, E. Neonatal enteropathies: defining the causes of protracted diarrhea of infancy. $J$ Pediatr Gastroenterol Nutr, v. 38, p. 16-26, 2004.

17. SCHNELL, U. et al. Absence of cell-surface EpCAM in congenital tufting enteropathy. Hum Mol Genet, doi: 10.1093/hmg/ddt105. Available at: <www.oxfordjournals.org/content/early/2013/03/05hmg. ddt105>. Accessed on: Dez. 03, 2013.

18. SCHNELL, U.; CIRULLI, G. B N. EpCAM: structure and function in health and disease. Biochim Biophys Acta, v. 33, art:e00030, doi 10.1042/ BSR20120128, 2013. Available at: <www.bioscirep.org/bsr/033/033e030. pdf>. Accessed on: Dez. 04, 2013.

19. SCHOFIELD, D. E. et al. Gastrointestinal microvillus inclusion disease. Am J Clin Pathol, v. 98, p. 119-24, 1992.

20. SIVAGNANAM, M. et al. Further evidence for EpCAM as the gene for congenital tufting enteropathy. Am J Med Genet A, v. 152 A, n. 1, p. 222-4, 2010 .

21. SIVAGNANAM, M. et al. Identification of EpCAM as the gene for congenital tufting enteropathy. Gastroenterology, v. 135, n. 2, p. 429-37, 2008 .

22. SOLIMAN, A. T. et al. Linear growth and circulating insulin-like growth factor I in children with tufting enteropathy receiving long-term TPN.J Pediatr Gastroenterol Nutr, v. 55, n. 2, p. 157-9, 2012.

\section{MAILING ADDRESS}

Karla Lais Pêgas

Santa Casa de Porto Alegre; Rua Prof. Annes Dias, 295; CEP: 90020-090; Porto Alegre-RS, Brazil; Phone: +55 (51) 3214-8409; Fax: +55 (51) 3214-8585;

e-mail: lfp.voy@terra.com.br. 